\title{
Application of a minimal glacier model to Hansbreen, Svalbard
}

\author{
J. Oerlemans ${ }^{1}$, J. Jania ${ }^{2}$, and L. Kolondra ${ }^{2}$ \\ ${ }^{1}$ Institute for Marine and Atmospheric research Utrecht, Utrecht University, P.O. Box 80005, \\ 3508 TA Utrecht, The Netherlands \\ ${ }^{2}$ Faculty of Earth Sciences, University of Silesia, ul. Bedzinska 60, 41-200 Sosnowiec, Poland
}

Received: 20 June 2010 - Published in The Cryosphere Discuss.: 13 July 2010

Revised: 24 November 2010 - Accepted: 10 December 2010 - Published: 3 January 2011

\begin{abstract}
Hansbreen is a well studied tidewater glacier in the southwestern part of Svalbard, currently about $16 \mathrm{~km}$ long. Since the end of the 19th century it has been retreating over a distance of $2.7 \mathrm{~km}$. In this paper the global dynamics of Hansbreen are studied with a minimal glacier model, in which the ice mechanics are strongly parameterised and a simple law for iceberg calving is used. The model is calibrated by reconstructing a climate history in such a way that observed and simulated glacier length match. In addition, the calving law is tuned to reproduce the observed mean calving flux for the period 2000-2008.

Equilibrium states are studied for a wide range of values of the equilibrium line altitude. The dynamics of the glacier are strongly nonlinear. The height-mass balance feedback and the water depth-calving flux feedback give rise to cusp catastrophes in the system.

For the present climatic conditions Hansbreen cannot survive. Depending on the imposed climate change scenario, in AD 2100 Hansbreen is predicted to have a length between 10 and $12 \mathrm{~km}$. The corresponding decrease in ice volume (relative to the volume in AD 2000) is 45 to $65 \%$.

Finally the late-Holocene history of Hansbreen is considered. We quote evidence from dated peat samples that Hansbreen did not exist during the Holocene Climatic Optimum. We speculate that at the end of the mid-Holocene Climatic Optimum Hansbreen could advance because the glacier bed was at least $50 \mathrm{~m}$ higher than today, and because the tributary glaciers on the western side may have supplied a significant amount of mass to the main stream. The excavation of the overdeepening and the formation of the shoal at the glacier terminus probably took place during the Little Ice Age.
\end{abstract}

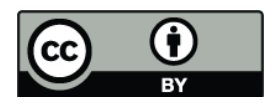

Correspondence to: J. Oerlemans (j.oerlemans@uu.nl)

\section{Introduction}

The long-term behaviour of a glacier is determined by its mass budget, i.e. the sum of accumulation, ablation and calving. These processes are first of all depending on the climatic and topographic setting, and less on the details of the ice mechanics. For instance, when the balance rate increases linearly with height, the net surface balance is entirely determined by the mean surface elevation. For a calculation of the surface balance it is thus sufficient to know a relation between the size of a glacier and its mean thickness. For shorter term fluctuations, annual or even seasonal, the role of ice mechanics becomes increasingly important, and then detailed models (and input data) are needed to simulate the behaviour of a glacier.

In this study Hansbreen, a tidewater glacier in Svalbard, is considered. The interest is in the behaviour of the glacier on a decadal to century time scale. A so-called minimal glacier model (Oerlemans, 2008) is used to investigate the global dynamics of this glacier. A minimal glacier model has no spatial resolution, i.e. it does not explicitly describe how quantities like ice thickness, basal water pressure, sliding velocity, etc., vary in space. The state variable is glacier length $L$. The mean ice thickness and the ice thickness at the glacier front are parameterised. Like in glacier models with spatial resolution, the evolution of the glacier is calculated from an integrated continuity equation. Normally this integration is done over a vertical coordinate to find a prognostic equation for the local ice thickness. In the case of a minimal model the integration is done over the entire glacier, as briefly described in Sect. 2. In the present study the mass balance is prescribed as a linear function of altitude, and the calving rate is assumed to be proportional to the water depth at the glacier front.

Hansbreen is a well studied glacier in SW Svalbard, located close to the Polish Research Station. Many investigations have been carried out on and close to this glacier

Published by Copernicus Publications on behalf of the European Geosciences Union. 
(e.g. Jania, 1988; Glazovsky et al., 1991; Jania et al., 1996; Vieli et al., 2002; Pälli et al., 2003). Hansbreen is currently about $16.5 \mathrm{~km}$ long and has a calving front of about $2 \mathrm{~km}$ wide (Fig. 1).

Surface mass balance has been measured since 1989. Data have been obtained from classic stake readings, done at the end of accumulation and ablation seasons (11 stakes along the centreline). A Digital Terrain Model of the glacier was updated every 5 years by precise kinematic GPS profiling. High frequency GPR profiling and snow pits studies have been carried out to map the distribution of accumulation.

The average winter balance rate is equal to $+0.95 \mathrm{~m}$ w.e., the summer balance rate to $-1.31 \mathrm{~m}$ w.e. and the net balance rate to $-0.36 \mathrm{~m}$ w.e., with large interannual variability. Mass loss due to calving contributes significantly to the total mass balance and was calculated as an equivalent of $-0.40 \mathrm{~m}$ w.e. (mean value for 2000-2008) up to $-0.85 \mathrm{~m}$ w.e. during the 2008/2009 balance year. Thus, the overall net mass balance of Hansbreen is about $-0.8 \mathrm{~m}$ w.e. The mean altitude of the equilibrium line, denoted by $E$ in this paper, equals $370 \mathrm{~m}$. The interannual variability of $E$ is large, with maximum and minimum values of $500 \mathrm{~m}$ and $260 \mathrm{~m}$ respectively during the last two decades of observations.

The average slope of the glacier surface is rather small $\left(1.6^{\circ}\right)$ and fairly constant (cf. Fig. 2b). Upstream of the current front the glacier bed is below sea level over a distance of about $10 \mathrm{~km}$ (Fig. 2a). In contrast to many other glaciers on Svalbard, Hansbreen probably did not surge during the past 150 years and perhaps it is not a surging glacier at all.

The front of Hansbreen has been retreating since the end of the 19th century. Hansbreen has been sketched on the first charts of the area made by the preparatory expedition on the ship "Isbjørn" of the Austrian-Hungarian North Pole Expedition during exploration of the Hornsund Fjord in 1871. It is unknown when Hansbreen reached its Little Ice Age (LIA) maximum size, but it is likely that this was in the second half of the 19th century. The glacier length record was compiled by a team of the University of Silesia. They based their compilation on old Russian Arch of Meridian Measurements Expeditions and Norwegian maps. Later, systematic Polish terrestrial photogrammetric surveys have been initiated (cf. Jania, 1988). The length record is shown in Fig. 3. The total retreat from 1900 until 2008 is about $2.7 \mathrm{~km}$ along the central flowline. On a timescale of a few years there are significant fluctuations with small advances, inherent to the dynamics of a calving glacier.

In this study the glacier model is calibrated by imposing several constraints. A history of the equilibrium line altitude $E(t)$ will be constructed in such a way that the observed length record is well simulated, and that the calving flux averaged over the period 2000-2008 matches the observed flux. The latter constraint determines the value of the empirical calving rate parameter.

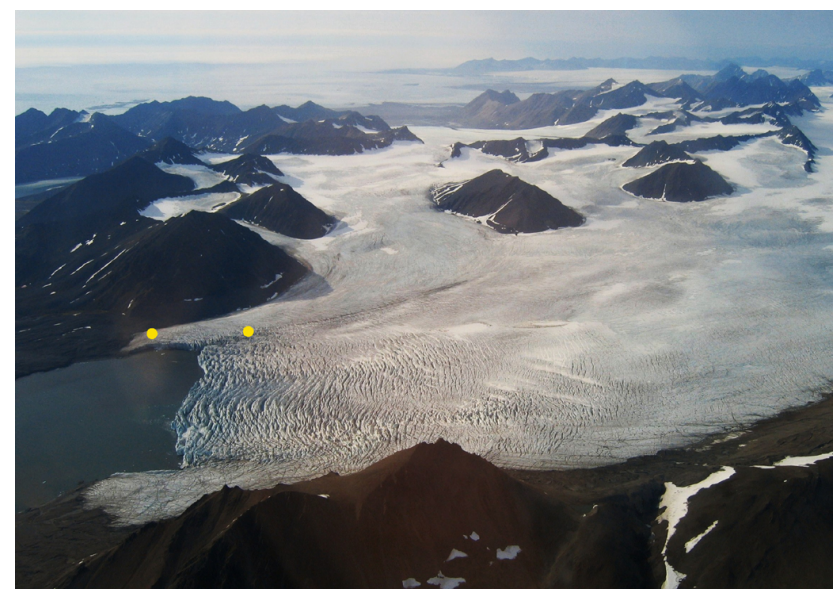

Fig. 1. Aerial of the lower part and calving front of Hansbreen. The yellow dots indicate locations were fossil peat was found at the surface in 1997 (discussed in Sect. 4). Courtesy of SLICES Project (Swansea Glaciology Group, Swansea University, UK).

Next the model is used to determine equilibrium states for a wide range of values of $E$. The solution diagram shows a double hysteresis, related to the height-mass balance feedback and the water depth-calving rate feedback. The apparent nonlinear response of Hansbreen to changes in climate has implications for understanding the advance-retreat cycle. In the last part of this paper the way in which the glacier could have advanced to its LIA maximum stand will be discussed.

\section{The model}

Although Hansbreen has some tributary glaciers, the addition of mass to the main stream is neglected in the present model. Furthermore, the glacier is assumed to have a constant width, which admittedly is only a crude representation of the real geometry (Fig. 2b). The set-up of the model as well as the parameterisation of the bed profile along the central flowline is shown in Fig. 4. The starting point for the model formulation is the continuity equation:

$\frac{\mathrm{d} V}{\mathrm{~d} t}=B_{\mathrm{s}}+F$,

where $V$ is total ice volume, $B_{\mathrm{S}}$ is the total surface balance rate, and $F(<0)$ is the calving flux. By definition, the volume equals the mean ice thickness $H_{\mathrm{m}}$ times glacier length, so

$\frac{\mathrm{d} V}{\mathrm{~d} t}=\frac{\mathrm{d}}{\mathrm{d} t}\left(H_{\mathrm{m}} L\right)=H_{\mathrm{m}} \frac{\mathrm{d} L}{\mathrm{~d} t}+L \frac{\mathrm{d} H_{\mathrm{m}}}{\mathrm{d} t}$

The mean ice thickness is parameterised as (Oerlemans, 2008):

$H_{\mathrm{m}}=\frac{\alpha_{\mathrm{m}}}{1+\nu \bar{s}} L^{1 / 2}$ 

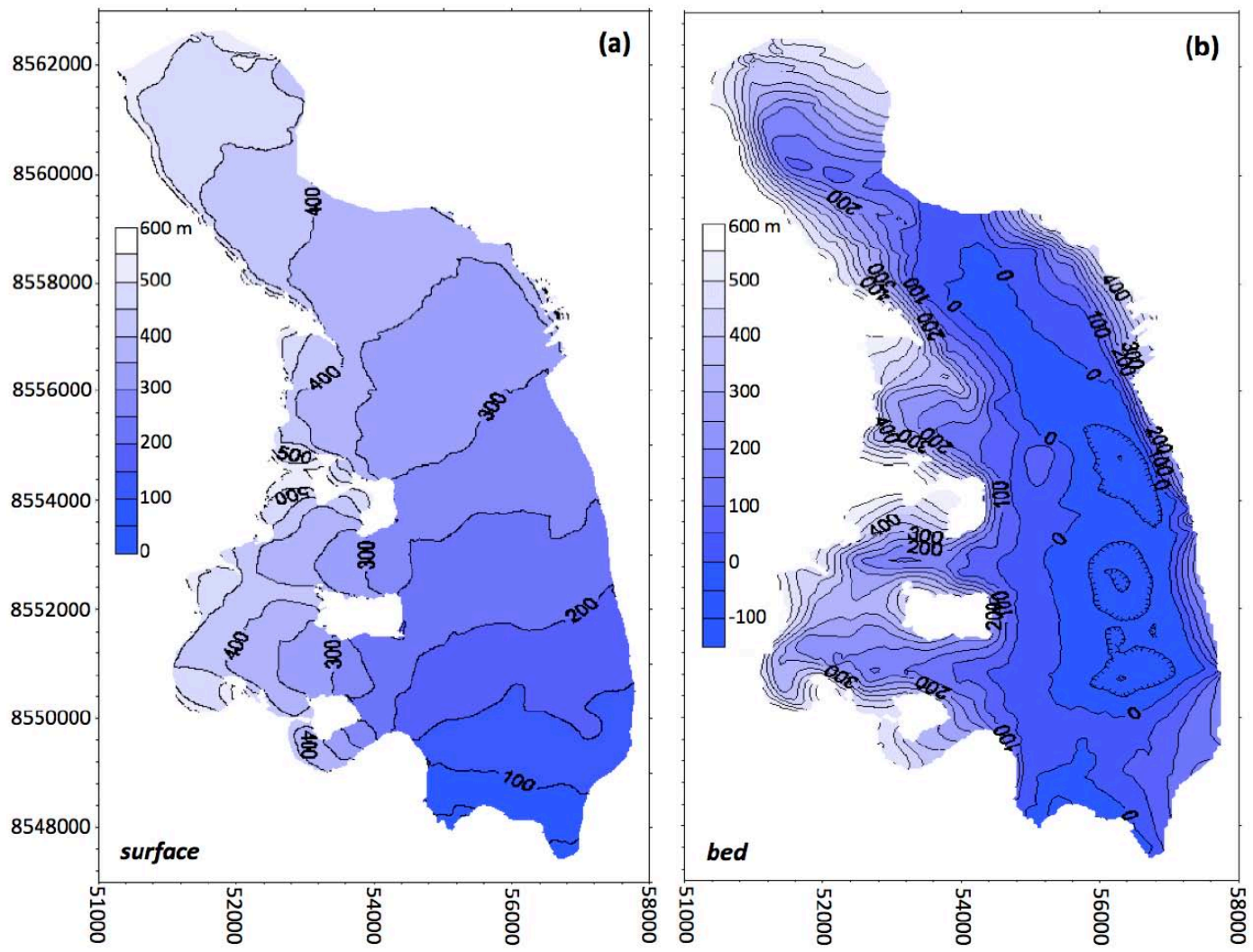

Fig. 2. Surface elevation (a) and bed topography (b) of Hansbreen (courtesy of Mariusz Grabiec, University of Silesia, personal communication, 2010).

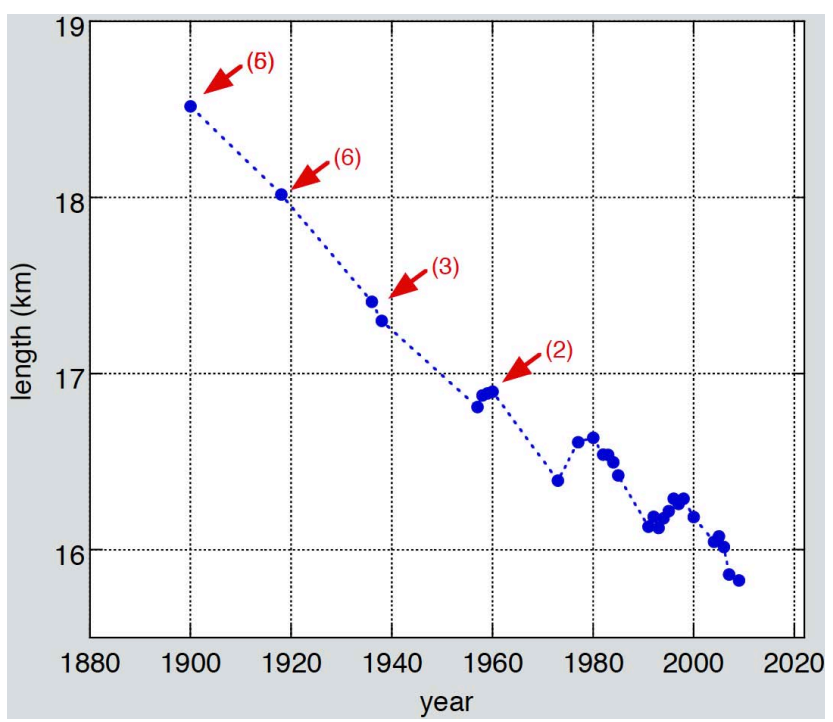

Fig. 3. The length record of Hansbreen. Arrows indicate data points that have been given a larger weight in the calibration procedure (weights given in brackets), as described in Sect. 3 . where $\bar{s}$ is the mean slope of the bed over the glacier length and $\alpha_{\mathrm{m}}$ and $v$ are constants. This expression gives a good fit to results from numerical flowline models. For $\bar{s} \rightarrow 0$ the mean thickness varies with the square root of the glacier length, which is in agreement with the perfectly plastic and Vialov solutions for a glacier/ice cap on a flat bed (Weertman, 1961; Vialov, 1958).

From Eq. (3) it follows that

$\frac{\mathrm{d} H_{\mathrm{m}}}{\mathrm{d} t}=\frac{\alpha_{\mathrm{m}}}{2(1+\nu \bar{s})} L^{-1 / 2} \frac{\mathrm{d} L}{\mathrm{~d} t}-\frac{\alpha_{\mathrm{m}} \nu}{(1+\nu \bar{s})^{2}} L^{1 / 2} \frac{\partial \bar{s}}{\partial L} \frac{\mathrm{d} L}{\mathrm{~d} t}$

Combining Eqs. (2) and (4) yields

$\frac{\mathrm{d} V}{\mathrm{~d} t}=\left\{\frac{3 \alpha_{\mathrm{m}}}{2(1+\nu \bar{s})} L^{1 / 2}-\frac{\alpha_{\mathrm{m}} \nu}{(1+\nu \bar{s})^{2}} L^{3 / 2} \frac{\partial \bar{s}}{\partial L}\right\} \frac{\mathrm{d} L}{\mathrm{~d} t}$.

The evolution of the glacier length can thus be calculated from

$\frac{\mathrm{d} L}{\mathrm{~d} t}=\left\{\frac{3 \alpha_{\mathrm{m}}}{2(1+\nu \bar{s})} L^{1 / 2}-\frac{\alpha_{\mathrm{m}} \nu}{(1+\nu \bar{s})^{2}} L^{3 / 2} \frac{\partial \bar{s}}{\partial L}\right\}^{-1} B_{\mathrm{s}}$.

The balance rate $\dot{b}$ is taken as a linear function of altitude $h$, according to: 


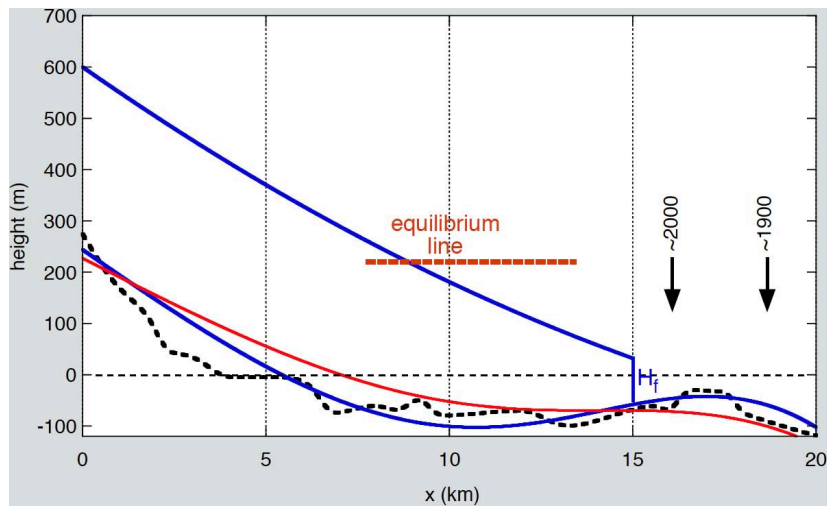

Fig. 4. Outline of the model for Hansbreen. The black dashed line is the bed elevation taken along a flowline (Fig. 2), whereas the blue line is the analytical representation used in the model. The red line shows an alternative profile used as a speculative approximation for the pre-Little Ice Age bed.

$\dot{b}=\beta(h-E)$,

where $\beta$ is the balance gradient.

In the case of a linear balance profile the calculation of $B_{\mathrm{s}}$ is straightforward, because

$B_{\mathrm{s}}=\beta \int_{0}^{L}(H(x)+b(x)-E) \mathrm{d} x=\beta\left(H_{\mathrm{m}}+\bar{b}-E\right) L$,

where $\bar{b}$ is the mean bed elevation over the glacier length.

A simple representation of the bed $b(x)$ with an overdeepening is obtained by superposing a Gaussian bump on a linearly sloping bed:

$b(x)=b_{0}-s x+b_{1} e^{-\left\{\left(x-x_{0}\right) / x_{l}\right\}^{2}}$.

The amplitude of the bump is determined by $b_{1}$, its location along the bed profile by $x_{0}$ and its width by $x_{l}$. The constant $s$ represents the linear part of the bed slope.

The mean bed elevation is calculated as

$\bar{b}=\frac{1}{L} \int_{0}^{L} b(x) \mathrm{d} x=b_{0}-\frac{s L}{2}+\frac{b_{1}}{L} \int_{0}^{L} e^{-\left\{\left(x-x_{0}\right) / x_{l}\right\}^{2}} \mathrm{~d} x$

With $x^{\prime}=\left(x-x_{0}\right) / x_{l}$ the last integral in Eq. (10) can be written as

$\int_{0}^{L} e^{-\left\{\left(x-x_{0}\right) / x_{l}\right\}^{2}} \mathrm{~d} x=x_{l}\left[\int_{0}^{\left(L-x_{0}\right) / x_{l}} e^{-x^{\prime 2}} \mathrm{~d} x^{\prime}-\int_{0}^{x_{0} / x_{l}} e^{-x^{\prime 2}} \mathrm{~d} x^{\prime}\right]$.

The integral is thus written as the sum of two values of the error function, for which standard approximations exist (e.g. Hamming, 1987).

The mean bed slope is easily obtained from Eq. (9):

$\bar{s}=s+\frac{b_{1}}{L} e^{\left.-\left\{\left(L-x_{0}\right) / x_{l}\right)\right\}}$.
Finally, after a bit of manipulation an expression for $\partial \bar{s} / \partial L$ is found (note that $\bar{s}$ is counted positive when the bed slopes down in the $x$-direction):

$$
\begin{aligned}
\frac{\partial \bar{s}}{\partial L} & =-\frac{b_{1}}{L^{2}}\left\{e^{-\left(x_{0} / x_{l}\right)^{2}}-e^{-\left[\left(L-x_{0}\right) / x_{l}\right]^{2}}\right\} \\
& +\frac{b_{1}}{L} \frac{2\left(L-x_{0}\right)}{x_{l}^{2}} e^{-\left[\left(L-x_{0}\right) / x_{l}\right]^{2}} .
\end{aligned}
$$

The calving rate is assumed to be proportional to the water depth $d$, so the calving flux can be written as

$F=-c d H_{\mathrm{f}}$,

where $H_{\mathrm{f}}$ is the ice thickness at the glacier front, and $c$ a constant of proportionality (the "calving parameter"). $\mathrm{Pa}$ rameterising the calving flux in this way has been suggested by, among others, Brown et al. (1982), Funk and Röthlisberger (1989), Pelto and Warren (1991), Björnsson et al. (2000). In recent years more comprehensive calving theories have been developed, looking at the interplay of different physical mechanisms and stressing the important role of crevasse formation and the type of sliding (for a comprehensive review, see Benn et al., 2007). In the present study the interest is in the global dynamics of a glacier system and its evolution on larger time scales. This justifies an approach in which only the bulk effects are taken into account. With respect to the total mass budget of a glacier, it is reasonable to assume that mass loss by calving is generally larger when the glacier front is in deeper water.

The thickness of the glacier front is taken as a fraction $\kappa$ of the mean ice thickness, unless the water depth is too large (Oerlemans and Nick, 2005):

$H_{\mathrm{f}}=\max \left\{\kappa H_{\mathrm{m}} ; \delta d\right\}$.

Here $\delta$ is the ratio of water density to ice density, implying that $\delta d$ is the thickness at which the glacier front just starts to float. The use of Eq. (15) allows the model glacier to undergo a smooth transition between a land-based terminus and a calving front.

Equation (6), with the expressions for $\bar{b}, \bar{s}$ and $\partial \bar{s} / \partial L$ included, is of the form

$\frac{\mathrm{d} L}{\mathrm{~d} t}=f\left\{L, P_{j}\right\}$.

Here $P_{j}$ is a set of parameters that vary in time and represent the "forcing" of the model glacier, like equilibrium-line altitude, sea level, etc. Since the equation is strongly damped, a simple forward or backward Euler method produces an accurate solution (e.g. Hamming, 1987). Denoting a time step by $\Delta t$ and a discrete time variable by $t_{i}$, the forward Euler scheme is formulated as

$$
\frac{L\left(t_{i}+\Delta t\right)-L\left(t_{i}\right)}{\Delta t}=f\left\{L\left(t_{i}\right), P_{j}\left(t_{i}\right)\right\},
$$


from which it follows that

$L\left(t_{i}+\Delta t\right)=L\left(t_{i}\right)+\Delta t f\left\{L\left(t_{i}\right), P_{j}\left(t_{i}\right)\right\}$.

In this study a time step of one year is used $(\Delta t=1 \mathrm{a})$.

Model parameters are taken from Oerlemans (2008; p. 70): $\alpha_{\mathrm{m}}=3 \mathrm{~m}^{1 / 2}, v=10, \kappa=0.4, \beta=0.006 \mathrm{~m}_{\text {ice a }}^{-1} \mathrm{~m}^{-1}$. These values ensure that the bulk characteristics of Hansbreen are reproduced, notably the mean thickness and the ice thickness at the glacier front. The calving parameter $c$ can be determined from observed calving rates. The calving rate in the model is entirely determined by the water depth and the glacier length (through the ice thickness). The mean calving rate for the period 2000-2008 has been estimated as equivalent to a balance rate of $-0.4 \mathrm{~m}$ w.e. This value is matched by the model if $c=1.15 \mathrm{a}^{-1}$.

\section{Calibration with the glacier length record}

Long meteorological records are available from various locations in Svalbard. Nørdli and Kohler (2004) have analysed these and constructed a composite temperature series for the Isfjorden region for the period 1910-2004. This appears to be the longest homogeneous record in Svalbard. The distance between Hansbreen and Isfjorden is about $120 \mathrm{~km}$. We may therefore assume that the slow variations in the Isfjorden temperature series are reasonably representative for the Hansbreen area as well. The most outstanding feature in this record is a period of significantly higher temperatures during the period 1920-1960 (Fig. 5a). This anomaly occurred in all seasons, albeit with significant differences in amplitude. The records also exhibit a linear trend, and in all seasons the highest temperatures have been observed in recent years. Information concerning changes in precipitation is scarce and indirect. Pohjola et al. (2002) have reconstructed a 300-yr series of annual accumulation rates from an ice core drilled at Lomonosovfonna, which is almost $200 \mathrm{~km}$ away from Hansbreen. Their results show a trend of increasing accumulation over the period 1720-2000. Around the year 1950 the accumulation rate jumps to a significantly higher level (Fig. 5b). During the period 1960-2000 the mean accumulation rate was about $0.4 \mathrm{~m}$ w.e., which should be compared to a value of about $0.3 \mathrm{~m}$ w.e. for the period 1720-1950.

As stated in the Introduction, the glacier model is calibrated by reconstructing a history of the equilibrium line altitude $E(t)$ which produces a good simulation of the observed length record. This can be done in several ways. The shortterm fluctuations in glacier length are a dynamical effect and not directly related to changes in the surface mass balance. If these fluctuations would nevertheless be used to reconstruct $E(t)$, very large and unrealistic values of $E$ would result. The length record should therefore be smoothed before it is used for the reconstruction of $E(t)$. An alternative approach is to prescribe $E(t)$ in a functional form, and determine the parameters by matching the simulated and observed glacier
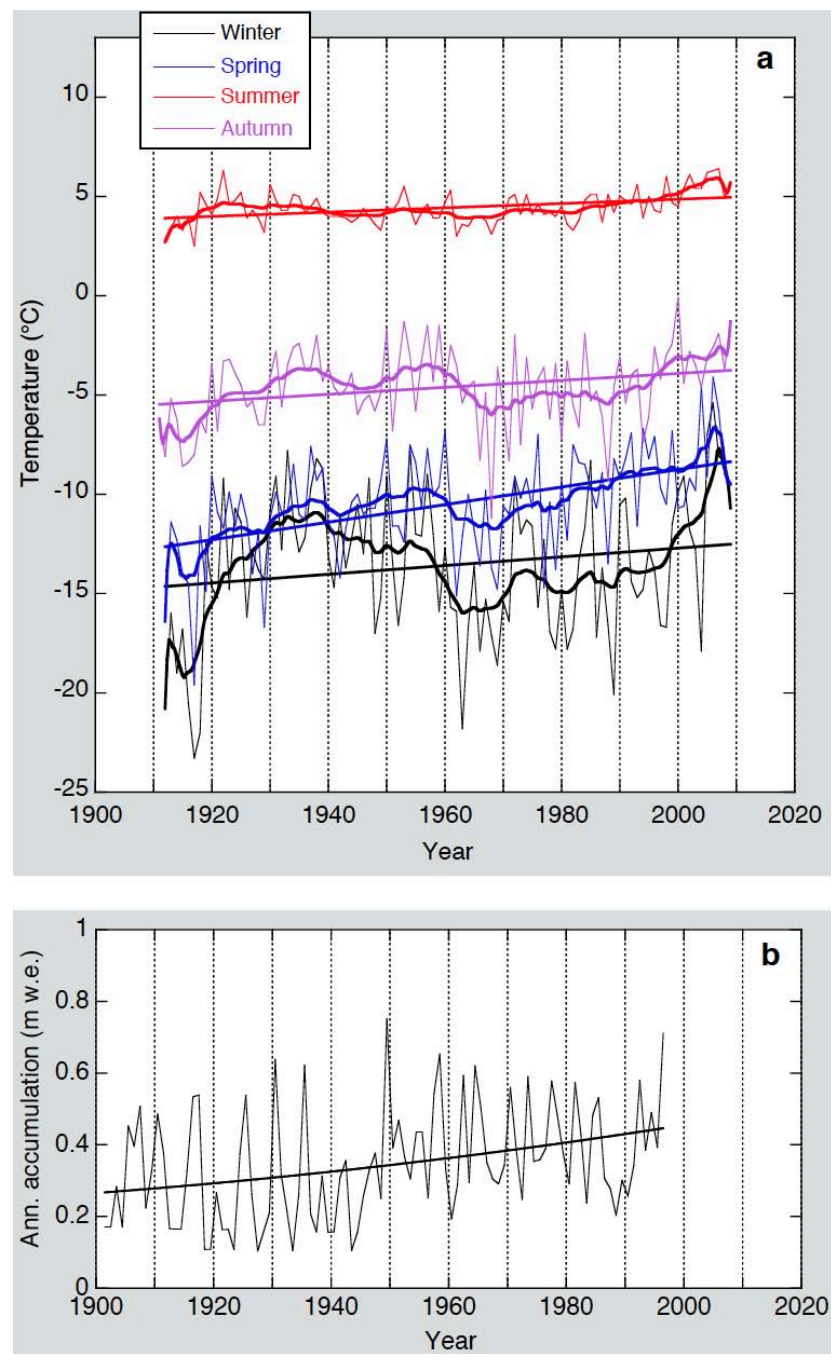

Fig. 5. (a) Homogeneous temperature series for the Isfjorden region (Nørdli and Kohler, 2004; with additions provided by these authors). Low-pass filtered curves and linear fits are shown for each season. (b) Annual accumulation reconstructed from an ice core drilled at the Lomonosovfonna ridge (Pohjola et al., 2002). The fit is a second-order polynomial.

length. Here, the latter approach has been taken, because there is a priori information available about climate change in Svalbard as prescribed above. We assume that the change in equilibrium-line altitude can be described as a linear trend on which a Gaussian function is superposed to represent the relatively warm period in the first half of the 20th century. Before the year $1850, E$ is kept constant because reliable information on climate change is not available. This implies that the modelled glacier in year 1850 represents an equilibrium state. We thus have:

$t<1850 \mathrm{AD}: \quad E(t)=E_{0}$, 


$$
\begin{array}{ll}
t \geq 1850 \mathrm{AD}: \quad & E(t)=E_{0}+E_{1}(t-1850) \\
& +E_{2} \exp \left[-\left\{\frac{t-t_{\mathrm{c}}}{P}\right\}^{2}\right],
\end{array}
$$

where time $t$ is in years. $P$ is the "width" of the warm period and $t_{\mathrm{c}}$ the year at which it is centered. Altogether there are five parameters for which optimal values should be found: $E_{0}, E_{1}, E_{2}, t_{\mathrm{c}}$ and $P$. The optimal values are found by minimising a cost function $\Psi$, defined by

$$
\Psi^{2}=\frac{\frac{1}{K} \sum_{k=1}^{K} w_{k}\left[L_{k, \mathrm{obs}}-L_{k, \mathrm{mod}}\right]^{2}}{\sum_{k=1}^{K} w_{k}} .
$$

The optimisation procedure is carried out with a simple random-walk method. Values of the parameters are perturbed at random, and the new values are retained when the corresponding value of $\Psi$ is lower than its value in the previous step. Convergence to a stable solution appears to be rapid. When different initial values of the control parameters are taken within reasonable limits, the solution turns out to be unique.

The results of the calibration are summarised in Fig. 6 . The parameter values found are: $E_{0}=255 \mathrm{~m}, E_{1}=$ $0.72 \mathrm{~m} \mathrm{a}^{-1}, E_{0}=157 \mathrm{~m}, t_{\mathrm{c}}=1925$ (year), $P=21 \mathrm{a}$. It is evident that the assumption of a simple equilibrium line history according to Eqs. (19)-(20) performs very well. In the year 2010, the equilibrium line is $80 \mathrm{~m}$ higher than in the year 1850 , but still significantly lower than the peak value during the warm period in the first half of the 19th century. If the equilibrium line continues to rise at the same rate, the model predicts a glacier length of about $12.2 \mathrm{~km}$ in the year 2100. The corresponding components of the mass budget are shown in Fig. 6b. The calving flux $F$ has been divided by the glacier area to obtain a number that has the same unit as the surface mass balance. Around the year 1905 the surface balance becomes negative. Although the calving flux has decreased slightly because the glacier front moves into shallower water, the total budget is strongly negative, reaching a

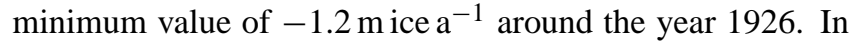
fact, according to the model the surface balance never becomes positive anymore afterwards. After the year 2000 the retreat of the glacier gradually accelerates because the front moves into deeper water and the calving flux increases. Mean ice thickness, and thickness and water depth at the front are shown in Fig. 6c. For most of the the time the frontal thickness is well above the buoyancy thickness, but around the year 2100 the water depth at the front has increased so much that the ice thickness approach the buoyancy thickness.

Several numerical experiments were performed to see how well $E(t)$ is defined by the calibration procdure. The minimum value of $\Psi$, equal to $0.097 \mathrm{~km}$ for the parameter values given above, increases smoothly when the control parameters are varied. As a further illustration, the dotted line in Fig. $6 a$
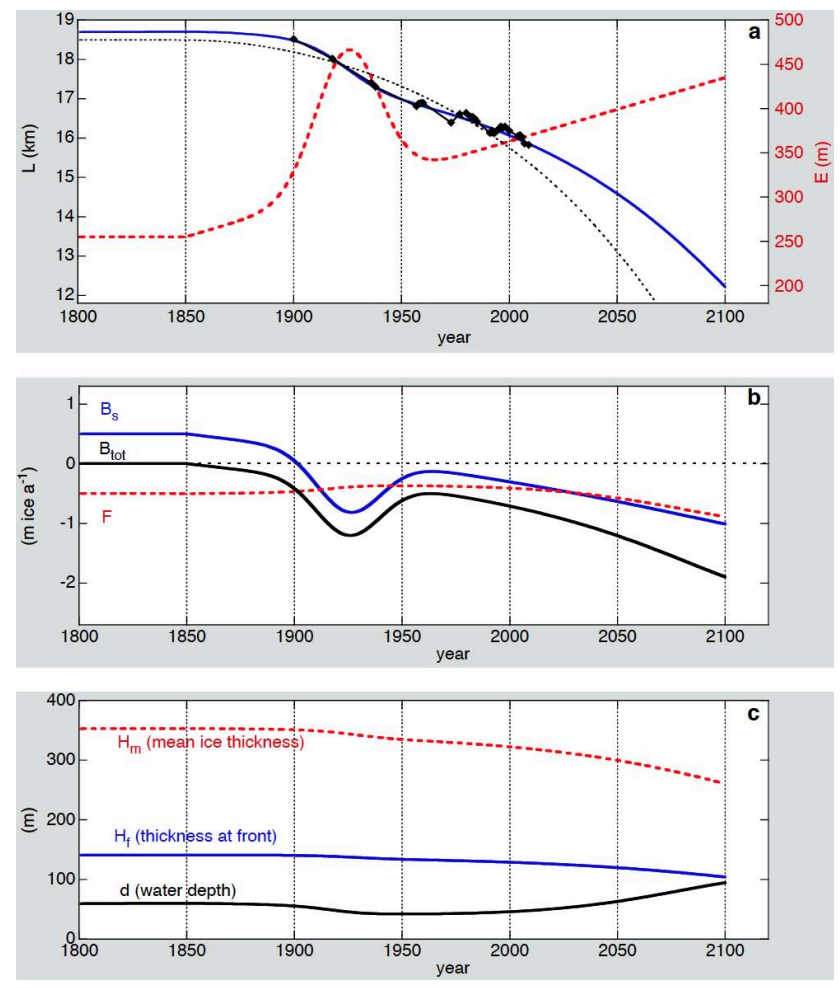

Fig. 6. (a) Simulated glacier length (blue), observations (black diamonds), and inferred equilibrium line altitude (red, dashed) for the calibration run. The corresponding components of the mass budget are shown in (b) and ice thickness and water depth at the front in (c). Note that the components of the mass budget have been divided by the length of the glacier to obtain the dimension of a mean balance rate. The black dotted line in (a) shows the best possible simulated glacier length if $E_{2}=0$, i.e. when the equilibrium line altitude is forced to increase linearly in time.

shows the best possible solution when $E_{2}=0$, i.e. when the equilibrium line altitude is allowed to vary only linearly in time. Apparently this gives a simulated glacier length history that is way off. No matter which value is chosen for $E_{1}$, the response of the model will be a glacier length that decreases more or less exponentially in time, which is not in agreement with the observed record. The behaviour of Hansbreen (and many other glacier in Svalbard) cannot be explained without a strong positive anomaly of $E$ the early half of the 20th century.

As noted above, the reconstructed current height of the equilibrium line is still lower than the peak value during the first half of the 20th century. This seems in disagreement with the temperature record (Fig. 5). However, the marked increase in accumulation in the second half of th 20th century referred to above (Fig. 5b) may explain why the reconstructed $E(t)$ does not quite follow the temperature (Fig. 5b). Energy balance modelling for many glaciers has shown that a $25 \%$ increase in precipitation would typically compensate for a $1 \mathrm{~K}$ warming. Therefore we think that the equilibrium 


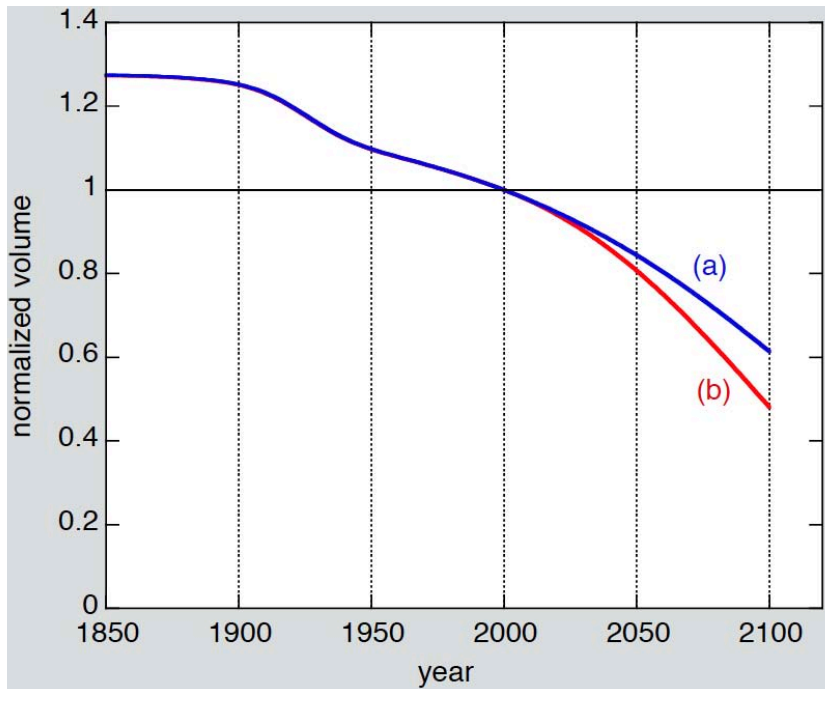

Fig. 7. Normalised ice volume for two different rates at which the equilibrium line rises from AD 2000 onwards: (a): $0.72 \mathrm{~m} \mathrm{a}^{-1}$; (b): $2.16 \mathrm{ma}^{-1}$.

line in Svalbard would have risen significantly more if the precipitation would have remained at the same level.

The glacier volume, normalised by its value in the year 2000, is shown in Fig. 7 (blue curve). For the calculation described above, the volume in the year 2100 is predicted to be $61 \%$ of the value in the year 2000 . The LIA maximum volume is $27 \%$ larger. For comparison, the volume curve calculated for a stronger warming scenario is also shown (red curve). In this case the rate at which the equilibrium rises is tripled in the year 2000 (i.e. $2.16 \mathrm{~m} \mathrm{a}^{-1}$ instead of $0.72 \mathrm{~m} \mathrm{a}^{-1}$ ). This implies that $E$ is about $550 \mathrm{~m}$ in the year 2100 , and virtually the entire glacier is below the equilibrium line. In this case the volume in the year 2100 is only $48 \%$ of that in the year 2000 .

In view of the projected warming for the Arctic region, a value of $2.16 \mathrm{~m} \mathrm{a}^{-1}$ for the rise of the equilibrium line is not unrealistic. Depending on the concurrent increase in precipitation, the associated temperature rise would be 2 to $3^{\circ} \mathrm{K}$ in the coming hundred years. However, we note that in reality the equilibrium-line altitude is more likely to change in a more irregular way. This will have some effect on the icevolume curves for the future. Nevertheless, we believe that the scenarios shown here provide a good order-of-magnitude estimate of the mass loss of Hansbreen that has to be expected.

A study of Hansbreen with a more detailed model has been carried out by Vieli et al. (2002). In their model, twodimensional (vertical plane) velocity and stress fields are calculated along a flowline with a finite element method. The calving rate is parameterised with a floatation-criterion method (Van der Veen, 1996). It is difficult to compare in some detail the results of Vieli et al. (2002) with the out-

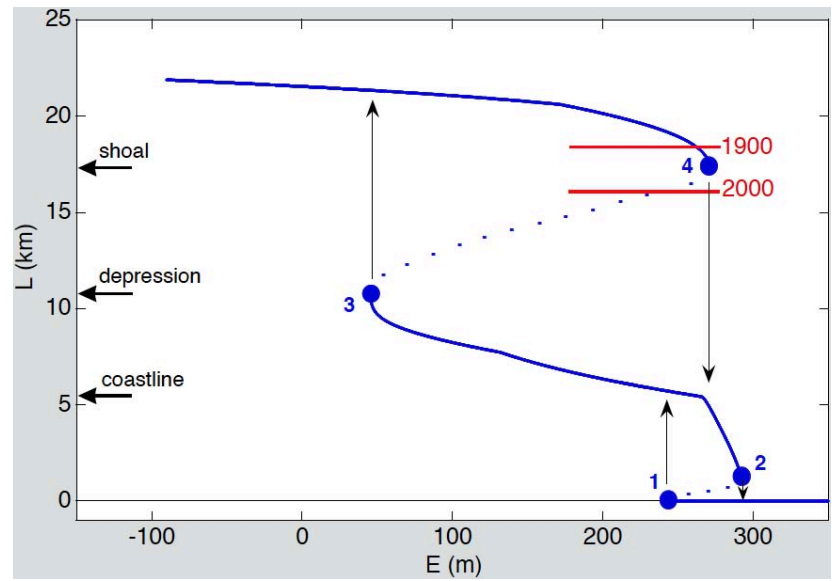

Fig. 8. Equilibrium states of Hansbreen calculated with the minimal model. The unstable equilibria are indicated by dotted lines. Arrows indicate the paths of the hystereses. Red bars give the approximate positions of the terminus in the years indicated. Critical points are numbered as described in the text.

come of the present study. Vieli et al. (2002) do not impose a change in climatic forcing and only simulate the behaviour for the period from 1936 onwards for a given fixed equilibrium line altitude of $333 \mathrm{~m}$. Judging from their Fig. 7 the rate of terminus retreat for the period 1936-2036 is about $19 \mathrm{~m} \mathrm{a}^{-1}$. Performing a similar calculation with the minimal glacier model, with the equilibrium line fixed at $333 \mathrm{~m}$, yields a value of $16.2 \mathrm{~m} \mathrm{a}^{-1}$. In view of the very different model characteristics, the rates of retreat are remarkably similar.

\section{Equilibrium states}

The simplicity of the model and the related computational efficiency allows a very fast determination of steady states. Because the existence of multiple equilibria is likely, integrations have to be performed with different initial conditions. The parameter space was investigated thoroughly, and as expected the most interesting behaviour is found for variations in $E$. Figure 8 shows the equilibrium states for a wide range of values of $E$. Multiple steady states are evident. In terms of dynamical systems theory, both the height-mass balance feedback and the water depth-calving flux feedback give rise to a cusp catastrophe. The cusp implies the possibility of three equilibrium states for a given value of $E$, of which the middle state is unstable (dotted in the figure).

Figure 8, with the double cusp, can be considered as the fundamental diagram depicting the relation between glaciers and climate (see also Oerlemans, 2008; chapter 6). The essential control parameters for the "calving cusp" are the amplitude of the overdeepening $b_{1}$ and the calving parameter $c$. The essential parameters for the "surface mass balance cusp" are the balance gradient $\beta$ and the parameter $\alpha_{\mathrm{m}}$, describing 
how strong the mean thickness of the glacier depends on its length (and here the bed slope thus appears to be an important parameter as well).

We now consider Fig. 8 in more detail. Coming from a warm climate without a glacier, lowering of the equilibrium line leads to the initiation of a glacier as soon as the equilibrium line hits the highest part of the bed (critial point 1; $E=245 \mathrm{~m}$ ). For the given model geometry, the glacier then grows to a length of about $5 \mathrm{~km}$, with a calving front in shallow water. Raising the equilibrium line makes the glacier shrink and can lead to a small glacier with the terminus on land. For $E>290 \mathrm{~m}$ the glacier has to disappear.

Once a glacier has been initiated, a further lowering of the equilibrium line makes the glacier larger, but it takes a value of $E$ below $46 \mathrm{~m}$ to let the glacier jump to the upper branche in Fig. 7, i.e. to allow the glacier front to pass the overdeepening in the bed. Stable equilibrium states with a glacier length between 10.8 and $17.5 \mathrm{~km}$ are not possible, which is the direct consequence of the reversed bed slope and the fact that the calving flux increases with the water depth. The mechanism is dynamically identical to the "marine ice sheet instability" introduced by Weertman (1974), and studied by many others with models of different complexity (e.g. Hindmarsh and Lemeur, 2001; Pattyn et al., 2006; Schoof, 2007). When the glacier is on the upper branche, it becomes rather insensitive to a further lowering of the equilibrium line. Because seaward of the shoal the bed slope is rather larger, only a small change in $L$ is needed to give a relatively large change in the calving flux.

The positions of the terminus of Hansbreen in the years 1900 and 2000 are indicated in the solution diagram (red lines). Since the equilibrium line has been far above an altitude of $250 \mathrm{~m}$ (critical point 4 ) for a long time now (see Fig. 6), the glacier cannot stay on the upper branche and in the end has to disappear. In fact, we may conclude that Hansbreen has been far away from equilibrium during at least the past hundred years.

\section{Speculations about the Holocene history of Hansbreen}

Like in many glacierized regions in the (sub-)Arctic, there are many indications from different sources that glaciers and ice caps were much smaller during the mid-Holocene Climatic Optimum (e.g. Svendsen and Mangerud, 1997; Baeten et al., 2007; Wanner et al., 2008). It has been suggested that between ca. 8800 and ca. 5000 years BP sea water temperatures around Svalbard were a few degrees $\mathrm{K}$ higher than today (Salvigsen et al., 2007; Hjort et al., 2007). It is thus very probable that the tidewater glaciers in the Hornsund area were much smaller than today, or even absent.

Evidence exists that Hansbreen, or at least the major part of its main stream, disappeared during the early Holocene. During the joint University of Silesia and Adam Mickiewicz
University expedition in 1997, fossil peat material melted out from the ice was found on the glacier surface. The peat was reworked by englacial transport along the longitudinal shear zone between the tributary Fuglebreen and the main tongue of Hansbreen, not far from the land-based lateral part of the front (Fig. 1). Samples were collected at locations about $50 \mathrm{~m}$ and $500 \mathrm{~m}$ upstream from the glacier front and were dated by the $\mathrm{C}^{14}$ method. The resulting uncalibrated dates were $7160 \pm 240 \mathrm{BP}$ (Gd-9998) and $5200 \pm 240 \mathrm{BP}$ (Gd-13000) (G. Rachlewicz, A. Mickiewicz, University in Poznań, personal communication, 2010). Later, more organic material that had melted out at the surface was found in the western part of Hansbreen. These findings prove that ice free conditions prevailed during the Holocene Climatic Optimum. The origin of the peat eroded by the glacier is most probably located on the surface of the raised marine terrace (ca. $10 \mathrm{~m}$ a.s.l.) of Holocene age, currently covered by the glacier. This morphological structure is evident in the subglacial topography along the western edge of the main tongue of Hansbreen (Fig. 2). The main part of the glacier bed is well below sea level (Fig. 2), and it is very likely that during the Holocene Climatic Optimum the main stream of Hansbreen did not exist at all.

After the Holocene climatic optimum the high northern latitude climate started to cool, mainly as a consequence of declining summer insolation. The cooling culminated in the little ice age (AD 1350-1850), which is now believed to be a combined response to the effects of orbital forcing, solar activity minima and strong volcanic eruptions (Wanner et al., 2008).

It is not known when Hansbreen started to form/advance and became the large tidewater glacier as we know it today. However, at some stage the glacier must have had a sufficiently large mass balance to advance, and to cross the overdeepened part of the bed. For the current bed profile, this would have required that the value of $E$ was less than $46 \mathrm{~m}$ (see Fig. 8; critical point 3), which is rather unlikely.

According to the classical model of Post (1975), a tidewater glacier advances by building a moraine shoal at the terminus which is carried along when the glacier front advances (implying continuous erosion and transportation of morainic material from underneath the glacial tongue to the terminus). The moraine shoal then limits the water depth at the front and thus reduces the loss of ice by calving. As a consequence the glacier can advance over a bed that is well below sea level. This mechanism has been investigated by Oerlemans and Nick (2005) with a minimum glacier model coupled to a simple scheme for sediment dynamics. With such a model one cannot proof that the Post model is realistic, because the details of the underlying physical processes are not explicitly considered. However, in terms of ice mass budgets, sediment budgets and resulting time scales for glacier evolution and decay, the mechanism of the migrating moraine shoal appears to be plausible. 
An alternative explanation for the LIA advance of tidewater glaciers over overdeepened beds is related to changing bed geometries. Perhaps in many cases valleys were less overdeepened than now seen in radar surveys. The lateHolocene history of Breidamerkurjökull provides an outstanding example (Björnsson, 1996). After AD 1400 Breidamerkurjökull started to expand over farmland, as has been described in historical documents. During the period 17321890 the glacier advanced over a distance of about $9 \mathrm{~km}$, excavating a 2 to $5 \mathrm{~km}$ wide trough up to $300 \mathrm{~m}$ deep. Björnsson (1996) calculates that in this period sediment was removed from the bed at an average rate of $0.7 \mathrm{~m} \mathrm{a}^{-1}$. In principle a similar mechanism may have operated for Hansbreen and other tidewater glaciers in Svalbard, although differences in the geographical setting have to be considered. For instance, the mass turnover of Breidamerkurjökull is typically about five times larger than that of Hansbreen. Also, the rate of sedimentation in Iceland, with its relatively soft volcanic deposits, is much larger than in the Hornsund area, where resistant metamorphic rocks of the Hecla Hoek formation dominate. The accumulation rate of sediments in the overdeepened part of the Hansbreen bed during midand late-Holocene times will have been low. Nevertheless, the deposition of for instance $50 \mathrm{~m}$ of sediment during perhaps 5000 years is a real possibility. The implied sedimentation rate of $1 \mathrm{~cm}$ per year is signifiantly less than sedimentation rates currently found in proglacial lakes in an igneous/metamorphic rock setting (e.g. Nigardsbreen, Norway; Østrem et al., 2005). In view of these considerations, the implication of the existance of a flatter bed profile prior to the LIA advance has been studied with the minimal glacier model.

In Fig. 4 a possible pre-LIA bed profile is shown by the red curve. This profile has been generated by simply adjusting the values of $b_{0}$ and $b_{1}$. The moraine shoal and the overdeepening have been largely removed, but the mean height of the bed over the 5 to $20 \mathrm{~km}$ range is not changed very much. The water depth at $x=10 \mathrm{~km}$ is now $50 \mathrm{~m}$ instead of $100 \mathrm{~m}$. The lower moraine shoal for pre-LIA bed profile is motivated by the idea that Hansbreen will have supplied material when it was in an advanced position during the LIA, before starting to retreat.

It appears that the different bed profile has a significant effect on the equilibrium states. Figure 9 shows a comparison of the solution diagrams for the original and pre-LIA bed profiles. For the pre-LIA profile the critical points 3 and 4 are much closer, and now a large tidewater glacier can form when $E$ is smaller than $199 \mathrm{~m}$ rather than the small value of $46 \mathrm{~m}$. So even a modest change in the bed profile can change the climatological thresholds significantly. A possible schematic path of Hansbreen in the $L, E$-plane is shown by the arrows in Fig. 9. In this interpretation a tidewater glacier would form at the End of the Holocene Climatic Optimum (stage I). In the beginning of the Little Ice Age the glacier starts to advance further, excavates the bed (by up to

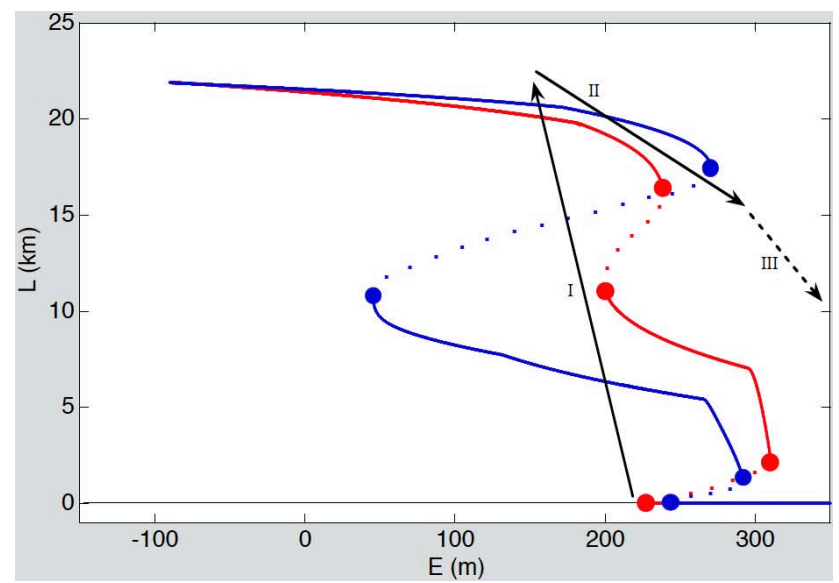

Fig. 9. Equilibrium states of Hansbreen for the present-day bed profile (blue) and assumed pre-LIA bed profile (red). The arrows shows a schematic path of the evolution of Hansbreen as described in the text.

$50 \mathrm{~m}$ ) and builts the moraine shoal as it exists today (stage II). The existence of the moraine shoal increases the critical $E$-value for decay (critical point 4 ) from 237 to $270 \mathrm{~m}$. The strong 20th century warming then raises the equilibrium line so much that the glacier passes the critical point on the upper branche and enters a phase of irreversible retreat (stage III).

It should be noted that glacio-isostatic rebound of the Svalbard region could also play a role in the scenario described above. However, for the second half of the Holocene changes in relative sea level for the Hornsund area were probably small (<10 m; e.g. Birkenmayer and Olsson, 1970; Boulton, 1979).

In addition to the possible effect of sediment transfer on the LIA advance of Hansbreen, it is very likely that the western tributary glaciers also played an important role in rebuilding Hansbreen. Presently, these tributary glaciers have higher accumulation rates than the main upper accumulation area of Hansbreen, which seems to be related to the re-deposition of blowing snow by frequent easterly winds. The assesment of the relative importance of the tributary glaciers for the LIA history of Hansbreen will require a 3-D modelling study in which the details of the geometry are taken into account (including a parameterisation of the spatial distribution of the accumulation rate).

\section{Summary and conclusions}

In this paper the overall dynamics of Hansbreen, Svalbard, were investigated by a minimal glacier model. For suitable model parameters a history of the equilibrium line altitude $E(t)$ could be derived that gives a perfect match between observed and simulated glacier length since AD 1900. This history is in agreement with other evidence on climate change in the Svalbard region. The rate of retreat calculated for the 
period 1936-2036 $\left(19 \mathrm{~m} \mathrm{a}^{-1}\right)$ appeared to be very similar to the value obtained by Vieli et al. (2004) from a more sophisticated model. According to the present model, the mean surface mass balance of Hansbreen has become negative around AD 1900 and never became positive again. Further credibility of the model is obtained from the fact that the model simulates the disappearance of Hansbreen for a small increase in $E$, in agreement with direct evidence for the disappearance of the main part of Hansbreen during the Mid-Holocene Climatic Optimum.

A study of the equilibrium states highlights the nonlinear character of the response of Hansbreen to climate change. The height-mass balance feedback as well as the water depthcalving rate feedback create hysteresis in the system. For the current bed profile, a value of $E$ as low as $46 \mathrm{~m}$ would be needed to create the large tidewater glacier as observed today. It seems more likely that at the end of the Holocene Climatic Optimum the bed underneath the present glacier was higher than today. A bed which is only $50 \mathrm{~m}$ higher appears to facilitate the growth of the glacier for a relatively modest drop in the equilibrium line altitude. We also note that the role of the western tributary glaciers in feeding and rebuilding the main stream of Hansbreen should not be underestimated, because these glaciers have relatively high cirques. However, the importance of the tributary glaciers can only be evaluated with a 3-dimensional model.

The model employed in this study is highly parameterized and does not incorporate the delicate ice-mechanical processes acting at and close to calving glacier fronts. Effects of a seasonal cycle in the calving rate or mini-surges cannot be dealt with. In a minimal glacier model the ice thickness is entirely determined by the glacier length. A retreating glacier of a given size therefore is not thinner than an advancing glacier of the same size, which introduces an error. It was also assumed that the glacier width is constant, and the effect of the tributary glaciers was not taken into account (note that these assumptions were also made by Vieli et al., 2004). Altogether, the present model cannot be more than a schematic representation of Hansbreen as it is observed in reality.

In spite of its obvious shortcomings, we believe that the minimal model captures the global dynamics of Hansbreen. Because of its simplicity it can be well calibrated with existing observational data. The components of the mass budget simulated by the model appear to be very realistic. The fact that Hansbreen is currently strongly out of balance with the prevailing climate is a robust result of this study, and also supported by the available observations collected by Polish scientists for this and other glaciers (Blaszczyk et al., 2009). The model results demonstrate clearly that the tidewater glaciers of Svalbard, with their low slopes and overdeepened beds, are extremely sensitive to climate change. A change in the equilibrium-line altitude of typically $150 \mathrm{~m}$ makes the difference between the presence of a large tidewater glacier, or no glacier at all.
We finally stress that even without further climate warming Hansbreen is doomed to disappear. Only a sustained lowering of the equilibrium line down to $250 \mathrm{~m}$ a.s.l. or less for a longer period of time would stop the glacier to decay. However, it is very unlikely that this will happen in the near future, having in mind the results of mass balance studies during last 20 years and changes in the glacier's geometry during the last century.

Acknowledgements. We wish to thank Darek Puczko and Mariusz Grabiec for preparation of recent unpublished observational data used in this study. Special thanks go to Grzegorz Rachlewicz for providing unpublished $\mathrm{C}^{14}$ dates of organic material melted out from the glacier. Data collection was carried out within the framework of the Polish contribution to the IPY Glaciodyn project, supported by the Ministry of Science and Higher Education under special grant No. IPY/269/2006.

We also thank Øvind Nordli (Norwegian Meteorological Institute) and Veijo Pohjola (University of Uppsala) for supplying the data used in Fig. 5.

Finally we are indebted to colleagues at the Institute for Marine and Atmospheric Research (Utrecht University) for making helpful comments on an earlier draft of this paper.

Edited by: C. O'Cofaigh

\section{References}

Baeten, N., Forwick, M., and Vorren, T.: Glacial activity and sedimentary processes in Billefjorden, Svalbard - preliminary results, 37th International Arctic Workshop, Program and Abstracts, Skaftafell, Iceland, 2-4 May 2007, The Earth Science Institute, University of Iceland, Reykjavik, 41-42, 2007.

Benn, D. I., Hulton, N. R. J., and Mottram, R. H.: "Calving laws", "sliding laws" and the stability of tidewater glaciers, Ann. Glaciol., 46, 123-130, 2007.

Birkenmayer, K. and Olsson, I. U.: Radiocarbon dating of raised marine terraces at Hornsund, Svalbard, and the problem of land uplift, Norsk Polarinstitutt Arbok 1969, 2-43, 1970.

Björnsson, H.: Scales and rates of glacial sediment removal: a $20 \mathrm{~km}$ long, $300 \mathrm{~m}$ deep trench created beneath Breidamerkurjökull during the Little Ice Age, Ann. Glaciol., 22, 141-146, 1996.

Björnsson, H., Pálsson, F., and Gudmundsson, S.: Jökulsárlón at Breidamerkursandur, Vatnajökull, Iceland: 20th century changes and future outlook, Jökull, 50, 1-18, 2000.

Blaszczyk, M., Jania, J. A., and Hagen, J. O.: Tidewater glaciers of Svalbard: Recent changes and estimates of calving fluxes, Pol. Polar Res., 30(2), 85-142, 2009.

Boulton, G. S.: Glacial history of the Svalbard archipelago and the problem of a Barentsz Shelf ice sheet, Boreas, 8, 31-57, 1979.

Brown, C. S., Meier, M. F., and Post, A.: Calving speed of Alaska tidewater glaciers with applications to the Columbia Glacier, Alaska, US Geol. Surv. Prof. Pap. 1258-C, 13 pp., 1982.

Funk, M. and Röthlisberger, H.: Forecasting the effects of a planned reservoir which will partially flood the tongue of Unteraargletscher in Switzerland, Ann. Glaciol., 13, 76-81, 1989. 
Glazovsky, A. F., Macheret, Yu. Ya., Moskalevsky, M. Yu., and Jania, J.: Tidewater glaciers of Svalbard, Glacier-OceanAtmosphere-Interactions, IAHS Publ. no. 208, 229-239, 1991.

Hamming, R.: Numerical methods for scientists and engineers, Dover Publ., 2nd edn., 721 pp., 1987.

Hindmarsh, R. C. A. and LeMeur, E.: Dynamical processes involved in the retreat of marine ice sheets, J. Glaciol., 47(157), 271-282, 2001.

Hjort, C., Mangerud, J., Adrielsson, L., Bondevik, S., Landvik, J. Y., and Salvigsen, O.: Radiocarbon dated common mussels Mytilus edulis from eastern Svalbard and the Holocene marine climatic optimum, Polar Res., 14(2), 239-243, 2007.

Jania, J.: Dynamiczne procesy glacjalne na południowym Svalbardie (w świetle badań fotointerpretacyjnych i fotogrametrycznych) [Dynamic glacial processes in South Svalbard (in the light of photointerpretation and photogrammetric research)], Uniwersytet Śląski, Katowice, 258 pp., 1988 (in Polish, English summary).

Jania, J., Mochnacki, D., and Gadek, B.: The thermal structure of Hansbreen, a tidewater glacier in southern Svalbard, Polar Res., 15, 53-66, 1996.

Nordli, Ø. and Kohler, J.: The early 20th century warming. Daily observations at Grønfjorden and Longyearbyen on Svalbard, DNMI/klima, report No. 12/03, 2004.

Oerlemans, J.: Minimal Glacier Models, Igitur, Utrecht University, 90 pp., 2008.

Oerlemans, J. and Nick, F. M.: A minimal model of a tidewater glacier, Ann. Glaciol., 42, 1-6, 2005.

Oerlemans, J. and Nick, F. M.: Modelling the advance-retreat cycle of a tidewater glacier with simple sediment dynamics, Global Planet. Change, 50, 99-111, 2006.

Østrem, G., Haakensen, N., and Olsen, H. C.: Sediment transport, delta growth and sedimentation in Lake Nigardvatn, Norway, Geogr. Ann., 87, 243-258, 2005.

Pälli, A., Moore, J. C., Jania, J., Kolondra, L., and Glowacki, P.: The drainage pattern of two polythermal glaciers: Hansbreen and Werenskioldbreen in Svalbard, Polar Res., 22(2), 355-371, 2003.

Pattyn, F., Huyghe, A., De Brabander, S., and De Smedt, B.: Role of transition zones in marine ice sheet dynamics, J. Geophys. Res., 111, F02004, doi:10.1029/2005JF000394, 2006.
Pelto, M. S. and Warren, C. R.: Relationship between tidewater glacier calving velocity and water depth at the calving front, Ann. Glaciol., 15, 115-118, 1991.

Pohjola, V. A., Martma, T., Meijer, H. A. J., Moore, J. C., Isaksson, E., Vaikmäe, R., and Van de Wal, R. S. W.: Reconstruction of three centuries of annual accumulation rates based on the records of stable isotopes of water from Lomonosovfonna, Svalbard, Ann. Glaciol., 35, 57-62, 2002.

Post, A.: Preliminary hydrography and historical terminal changes of Columbia Glacier, U.S. Geological Survey Hydrologic Investigations Atlas HA-559, 1975.

Salvigsen, O., Forman, S. L., and Miller, G. H.: Thermophilous molluscs on Svalbard during the Holocene and their paleoclimatic implications, Polar Res., 11(1), 1-10, 2007.

Schoof, C.: Marine ice sheet dynamics. Part I: The case of rapid sliding, J. Fluid Mech., 573, 27-55, 2007.

Svendsen, J. I. and Mangerud, J.: Holocene glacial and climatic variations on Svalbard, Svalbard, The Holocene, 7, 45-57, 1997.

Van der Veen, C. J.: Tidewater calving, J. Glaciol., 42(141), 375385, 1996.

Vialov, S. S.: Regularities of glacial shields movement and the theory of plastic viscous flow, Int. Assoc. Hydrol. Sci. Publ., 47, 266-275, 1958.

Vieli, A., Jania, J., and Kolondra, L.: The retreat of a tidewater glacier: observations and model calculations on Hansbreen, Svalbard, J. Glaciol., 48(163), 592-600, 2002.

Wanner, H., Beer, J., Butikofer, J., Crowley, T. J., Cubasch, U., Fluckiger, J., Goosse, H., Grosjean, M., Joos, F., Kaplan, J. O., Kuttel, M., Muller, S. A., Prentice, I. C., Solomina, O., Stocker, T. F., Tarasov, P., Wagner, M., and Widmann, M.: Mid- to Late Holocene climate change: an overview, Quaternary Sci. Rev., 27(19-20), 1791-1828, 2008.

Weertman, J.: Stability of ice-age ice sheets, J. Geophys. Res., 66, 3783-3792, 1961.

Weertman, J.: Stability of the junction of an ice sheet and an ice shelf, J. Glaciol., 13, 3-11, 1974. 